\title{
THE INFLUENCE OF NUTRITIONAL INFORMATION UPON CUSTOMER ATTITUDE AND BEHAVIOUR IN EATING OUT ESTABLISHMENTS
}

\section{Dagmara Stangierska1 , Iwona Kowalczuk², Monika Świątkowska², Hanna Górska-Warsewicz²}

${ }^{1}$ Section of Horticultural Economics, Faculty of Horticulture, Biotechnology and Landscape Architecture, Warsaw University of Life Sciences (SGGW-WULS), 159C Nowoursynowska Street, 02-787 Warsaw, Poland ${ }^{2}$ Department of Organization and Consumption Economics, Faculty of Human Nutrition and Consumer Sciences, Warsaw University of Life Sciences (SGGW-WULS), 159C Nowoursynowska Street, 02-787

Warsaw, Poland

\begin{abstract}
Background. Providing nutritional information in catering establishments in Poland, it is not mandatory, at the same time this type of information may affect the attitudes and behavior of consumers.

Objective. The purpose of this research was to define the influence of nutritional information upon customer attitude and behaviour in eating out establishments.

Material and methods: An online consumer survey was conducted in 2016. The quantitative research was undertaken in the form of a questionnaire among a group of 403 people selected in terms of age (18-35 years old), residence (big cities) and frequency of eating out or away from the home.

Results. The results of this research show that the respondents' perception of information was positive and influenced both their perception of the eating out establishment, as well as their purchasing decisions. Only gender was statistically important for the differentiation of the consumers' behaviour within the scope analyzed.

Conclusions. The results obtained lead to the conclusion that providing nutritional information may increase the competitiveness of eating out establishments. It may also lead to a more rational marketplace, where choices in terms of health may impact social health, taking into consideration the growing popularity of eating out or away from home.
\end{abstract}

Key words: nutritional information, eating out establishments, consumer behaviour

\section{STRESZCZENIE}

Wprowadzenie: Dostarczanie informacji o wartościach odżywczych w placówkach gastronomicznych w Polsce nie jest obowiązkowe, a tego typu informacje mogą wpływać na postawy i zachowania konsumentów.

Cel badań: Celem tego badania było określenie wpływu informacji o wartości odżywczej na postawy i zachowania klientów w lokalach gastronomicznych.

Material i metody: Badanie konsumenckie zostało przeprowadzono przez Internet w 2016 r. Badania ilościowe przeprowadzono w formie ankiety wśród 403 osób wybranych pod względem wieku (18-35 lat), miejsca zamieszkania (duże miasta) i częstotliwości spożywania posiłków poza domem.

Wyniki: Wyniki badań pokazują, że postrzeganie informacji przez respondentów było pozytywne i wpłynęło zarówno na ich postrzeganie placówki gastronomicznej, jak i na decyzje zakupowe. Tylko płeć była statystycznie istotna dla zróżnicowania zachowań konsumentów w analizowanym zakresie.

Wnioski: Uzyskane wyniki prowadzą do wniosku, że dostarczanie informacji żywieniowych może zwiększyć konkurencyjność lokali gastronomicznych. Może to również prowadzić do bardziej racjonalnego rozwoju rynku, gdzie wybory w zakresie zdrowia mogą wpływać na zdrowie społeczne, biorąc pod uwagę rosnącą popularność jedzenia poza domem.

Słowa kluczowe: informacje o wartościach odżywczych, lokale gastronomiczne, zachowania konsumentów

\footnotetext{
*Corresponding author: Section of Horticultural Economics, Faculty of Horticulture, Biotechnology and Landscape Architecture, Warsaw University of Life Sciences (SGGW-WULS), 159C Nowoursynowska Street, 02-787 Warsaw, Poland, Tel.: +48 225932021 , e-mail: dagmara_stangierska@sggw.pl;
} 


\section{INTRODUCTION}

In recent years, in EU countries and in the USA offer by eating out establishments has become more diversified [7]. Also the demand for gastronomic services has grown, and this has been boosted by economic changes (increase of income), demographic changes (increase of households of 1 or 2 persons), social and professional changes (increase of women's professional activity) and cultural (changes of lifestyle) [38].

As a result the meals eaten in eating out establishments have a considerable influence upon the consumers' diet $[4,20,21,35,41]$. Moreover, the gastronomy sector has begun to play an important role in the realisation of nutrition policy [24] by shaping consumers' nutritional habits. This in turn is what determines the necessity to pay particular attention to the nutritive aspect of meals served by eating out establishments [14].

Gastronomy may play an important role in the popularisation of healthy nutrition. One of the activities undertaken in this field is the education of consumers by giving the nutritional information of meals served [18]. The information may be placed on trays, in folders, menu cards or menu boards [1]. Providing nutritional information of meals served in gastronomy establishments is a more frequent practice $[14,16,40,41]$.

Opinions about the influence of nutritional information on consumer behaviour in gastronomy are not unambiguous.

According to Burton et al. [6], the availability of nutritional information in eating out establishments may limit the consumption of unhealthy food. In the opinion of Bollinger et al. [5], information on the caloric value of dishes may positively influence the decisions of clients without negative impact on the foodservice sector because consumers are ready to pay higher prices for healthier products $[17,31,33]$. On the other hand, Harnack and French [15], Krukowski et al. [23] have found that information on the caloric value of meals in eating out establishments does not influence consumer behaviour a lot. But in opinion of VanEpss et al. [36] restaurant menu labeling should not be expected to reduce energy consumption by enough to address obesity on its own, but it should be viewed as a reasonable place to start.

Mayfield [25], Mills and Thomas [27] have noticed that it is particularly important for clients of eating out establishments to have information on the amount of fats, saturated fats and trans fats. Josiam and Foster [19] have obtained similar results. They have in addition stated that female consumers aged between 35-65, people who were 'well-situated' and educated and people who care about healthy nutrition were particularly interested in nutritional information. Also Radwan et al. [30] noticed that young females are seen to favor menu labeling restaurants.

Providing nutritional information in gastronomy establishments is relatively rare in Poland where nutritional information is mostly, only given by foreign restaurant chains. In some domestic eating out establishments only iconographic identifiers are used (products for vegetarians, light products, etc.). Taking into account the fact that Poles are eating out more and more in the gastronomy sector [22], at the same time more and more are suffering from obesity and associated diseases [41]. It seems, as a result, therefore, to be important to analyse the influence of the nutritional information provided in eating out establishments on the Polish consumers' attitude and behaviour. This was the aim of the research undertaken.

The following research questions have been formed:

1. What are the consumers' opinions about the nutritional information placed in eating out establishments?

2. Does nutritional information provided at eating out establishments influence the customers' purchasing decisions?

3. Does nutritional information influence the customers' perception of eating out establishments?

\section{MATERIAL AND METHODS}

To find the answers to the research questions formulated, a quantitative research (carried out with use an original questionnaire, based on literature review) was conducted (in June 2016). The sample consisted of 403 respondents selected purposefully. Criteria of the selection were: age (between 18 and 35 ), living in big cities and eating out of the home in the last 3 months. The research was conducted using the method of an online survey.

Men and women were of almost equal number in the group surveyed. Over $50 \%$ of respondents visited bars and restaurants at least once a week. The average age of the respondent was 28. Almost half declared they had a higher education (Table 1).

Table 1. Description of population surveyed

\begin{tabular}{|c|c|}
\hline Specification & $\%$ \\
\hline \multicolumn{2}{|c|}{ Gender } \\
\hline Women & 50.87 \\
\hline Men & 49.13 \\
\hline \multicolumn{2}{|c|}{ Frequency of attendance at eating out establishments } \\
\hline Several times a week & 25.80 \\
\hline Once a week & 26.55 \\
\hline 2-3 times a month & 27.30 \\
\hline Once a month & 13.65 \\
\hline Once a quarter & 6.70 \\
\hline \multicolumn{2}{|c|}{ Age } \\
\hline $18-29$ & 53.85 \\
\hline $30-35$ & 46.15 \\
\hline \multicolumn{2}{|c|}{ Education } \\
\hline Primary, vocational, secondary & 51.12 \\
\hline Higher & 48.88 \\
\hline
\end{tabular}


In the main part of the survey a 5-point Likert scale was used (where: 1-strongly disagree, 2-disagree, 3 -undecided, 4-agree, and 5-strongly agree). From the twelve statements used we formed three indicators: indicator of perception of nutritional information (PNII), indicator perception of eating out establishment (PEOEI) and indicator of declared purchasing behaviour (DPBI).

\section{Perception of nutritional information indicator}

Perception of nutritional information indicator (PNII) described the respondents' attitude towards nutritional information. It was composed of four statements:

- nutritional information is given understandably (PNI1),

- nutritional information is useful and important from the nutritional point of view (PNI2),

- nutritional information influences more deliberate and reasonable choices (PNI 3),

- nutritional information should be available in eating out establishment in a visible place (PNI4).

\section{Perception of eating out establishment indicator}

Perception of eating out establishment indicator (PEOEI) was supposed to specify the respondents' attitude towards eating out places providing nutritional information, with the consideration of four statements:

(1) eating out establishments which provide nutritional information influence my confidence (PEOE1),

(2) providing nutritional information in eating out establishments means that they are innovative (PEOE2),

(3) providing nutritional information in eating out establishments means that they have high-quality services or dishes on offer (PEOE3),

(4) an eating out establishment, where nutritional information is given, has a healthier offer than others that do not provide such information (PEOE4).

\section{Declared purchasing behaviour indicator}

Declared purchasing behaviour indicator (DPBI) allowed us to recognise the respondents' intentions as regards to eating away from the home, considering the provision of nutritional information. It was composed of four statements:

- while choosing food, I rely on nutritional information (DPB1),

- the knowledge of a meal's nutritional value would influence my choice of a meal (DPB2),

- I'd rather eat in a place where nutritional and caloric information about the product is available (DPB3),

- caloric value placed in a visible place, nearby the product, would make it easier for me to choose a dish (DPB4),

\section{Research model}

The research also assumed that there is a correlation between the consumers' perception of nutrition information (PNII) and the perception of an eating out establishment (PEOEI) and declared purchasing behaviour (DPBI).

\section{Statistical analysis}

The results obtained were subject to statistical analysis using the Statistica 10 program.

The values of the indicators analysed were calculated as an arithmetical average with conformity of the assessment of responses to the statements, which consisted of particular indicators. The only feature of a consumer, which made a difference between the results obtained, was that of gender and this was assumed as the grouping variable in the analysis results. To compare the differences in compliance with particular statements (measured in the 5-degree Likert scale) the U Mann-Whitney test was used because of the gender issue. To compare the differences of the average indicators PNII, PEOEI, PBI depending on gender, the t-Student test was applied. Pearson correlation analysis was also made in order to check the dependencies assumed in the research model. In all analyses, the level of statistical importance has been assumed as $\mathrm{p} \leq 0.05$.

\section{RESULTS AND DISCUSSION}

As far as perception of nutritional information is concerned, the respondents declared a high compliance with most statements, except for the opinion, that "nutritional information is given understandably" (PNI1) (Table 2). One of the reasons for this phenomenon should be considered as the result of the low scale of education concerning nutrition within the scope of nutritional information in Poland [28]. The research completed so far shows that the level of knowledge regarding nutrition has a considerable influence on perception, evaluation and use of nutritional information [2,23]. Another reason for the poor understanding of information about nutrition may be that too much information is given, which also limits the possibility of using it $[1,30,32]$.

Most respondents, highly valued the usefulness of nutritional information, the need for its provision in eating out establishments and also where the information is shown i.e. in an easily visible place (PNI4) (Table 2). Analogical opinions were noted in effect in other research concerning this issue $[3,9,32]$.

The analysis of respondents' opinions on the statements accounting for the perception of an eating out establishment (PEOEI) showed, that providing nutritional information influences the increase of trust towards an eating out establishment (PEOE1) as well as the perception of quality of the meals offered (PEOE3) (grades 3.96 and 3.91) (Table 2). Also in the opinion of Thomas and Mills [34] eating out establishments that 
provide nutritional information have the consumers' confidence and offer, in the clients opinion, better quality meals. Moreover, Din et al. [9] suggest that consumers will more often choose eating out establishments where nutritional information is given, and as a result may force the establishment to offer meals with a healthier, and higher nutritional value [37, 39].

Lower grades of compliance were noted for the statements about innovativeness, and the healthier food on offer by the eating out establishments, which provided nutritional information (3.78 and 3.63) (Table 2). A reason for this may be that nutritional information is most often provided by network enterprises (overseas food chains for example), which offer fast food and are accused of a low nutritive value of their products [2].

Accounting for the elements regarding declared purchasing behaviour indicator (DPBI), it was stated that the highest compatibility (3.88) was for the statement concerning consumer preference of eating out establishments, which provide nutritional information (DPB3). Lower grades (3.66-3.7) have been noted for statements about the influence of nutritional information upon the choice of products offered in eating out establishments (DPB1, DPB2, DPB4) (Table 2). Also, in the opinion of Auchincloss et al. (2013), for the consumer the very fact of the provision of nutritional information is important, even if it is not used/referred to. Other research also suggests that nutritional information is not perceived as the key factor for choosing a meal in a restaurant $[3,11,1,29]$.

The correlation analysis between the level of compliance with the statements and features of respondents showed that statistically important differences appear only in the case of gender. Women have expressed greater compatibility with all the statements of the PNI indicator. As far as the PEOEI indicator is concerned, the evaluation given by women were higher for statements PEOE1, PEOE3, PEOE4, whereas regarding the DPB indicator women declared a higher compliance with statements DPB2 and DB3 (Table 2). This suggests that women are more aware of nutritional information, which has also been stated in other research $[8,9,10,26,31]$. Women are also more determined when it comes to the introduction of changes in the nutrition model and this further embraces the use of nutritional information while choosing dishes at an eating out establishment [13, 42].

After averaging out the results obtained, the highest rating was obtained for the indicator statement (forming individual indicators) where it was stated that in the general, the best evaluation/score was obtained for indicators PEOEI (3.82) and PNII (3.73). Mark 3.72 was noted in terms of the DPBI indicator.

Table 2. Respondents' compliance with statements that make up indicators of perception of nutritional information, perception of an eating out establishment and declared purchasing behaviour accounting for gender

\begin{tabular}{|c|c|c|c|c|c|c|c|}
\hline \multirow{2}{*}{ Statements } & \multicolumn{2}{|c|}{ Total } & \multicolumn{2}{|c|}{ Women } & \multicolumn{2}{|c|}{ Men } & \multirow{2}{*}{$\begin{array}{l}\text { p-value } \\
\text { (UWM } \\
\text { test) }\end{array}$} \\
\hline & Mean & $\mathrm{SD}$ & Mean & SD & Mean & $\mathrm{SD}$ & \\
\hline \multicolumn{8}{|c|}{ Perception of nutritional information (PNI) } \\
\hline $\begin{array}{l}\text { PNI1 } \\
\text { Nutritional information is easy to understand (PNI1), }\end{array}$ & 2.881 & 1.142 & 3.000 & 1.167 & 2.758 & 1.105 & 0.042 \\
\hline $\begin{array}{l}\text { PNI2 } \\
\text { Nutritional information is useful and important, from the point of view of nutrition (can delete) }\end{array}$ & 4.072 & 0.905 & 4.239 & 0.802 & 3.899 & 0.972 & 0.001 \\
\hline $\begin{array}{l}\text { PNI3 } \\
\text { Nutritional information influences more deliberate and reasonable choices }\end{array}$ & 3.943 & 0.962 & 4.073 & 0.944 & 3.808 & 0.963 & 0.005 \\
\hline $\begin{array}{l}\text { PNI4 } \\
\text { Nutritional information should be available in eating out establishments in a visible place }\end{array}$ & 4.007 & 0.882 & 4.146 & 0.833 & 3.864 & 0.911 & 0.003 \\
\hline \multicolumn{8}{|c|}{ Perception of an eating out establishment (PEOE) } \\
\hline $\begin{array}{l}\text { PEOE1 } \\
\text { Eating out establishments which provide nutritional information influence my confidence }\end{array}$ & 3.963 & 0.887 & 4.112 & 0.887 & 3.808 & 0.863 & 0.000 \\
\hline $\begin{array}{l}\text { PEOE2 } \\
\text { Providing nutritional information in eating out establishments means that they are innovative }\end{array}$ & 3.779 & 0.964 & 3.912 & 0.919 & 3.641 & 0.991 & 0.006 \\
\hline $\begin{array}{l}\text { PEOE3 } \\
\text { Providing nutritional information in eating out establishments means that they have higher- } \\
\text { quality on offer (services or dishes) }\end{array}$ & 3.906 & 0.965 & 3.976 & 0.977 & 3.833 & 0.949 & 0.108 \\
\hline $\begin{array}{l}\text { PEOE4 } \\
\text { An eating out establishment where nutritional information is given has a healthier offer than } \\
\text { one which does not provide it }\end{array}$ & 3.625 & 1.116 & 3.761 & 1.083 & 3.485 & 1.134 & 0.013 \\
\hline \multicolumn{8}{|l|}{ Declared purchasing behavior (DPB) } \\
\hline $\begin{array}{l}\text { DPB1 } \\
\text { While choosing a meal, I rely on nutritional information }\end{array}$ & 3.660 & 1.118 & 3.771 & 1.048 & 3.545 & 1.177 & 0.080 \\
\hline $\begin{array}{l}\text { DPB2 } \\
\text { Knowledge of nutritional value would influence my choice of a meal }\end{array}$ & 3.695 & 1.094 & 3.820 & 1.049 & 3.566 & 1.128 & 0.027 \\
\hline $\begin{array}{l}\text { DPB3 } \\
\text { I'd rather eat in a place where nutritional and caloric information about the product is available }\end{array}$ & 3.876 & 1.015 & 4.039 & 0.944 & 3.707 & 1.059 & 0.002 \\
\hline $\begin{array}{l}\text { DPB4 } \\
\text { Caloric value placed in a visible place nearby the product would make it easier for me to } \\
\text { choose a dish }\end{array}$ & 3.682 & 1.085 & 3.780 & 1.087 & 3.581 & 1.076 & 0.054 \\
\hline
\end{tabular}


The result of the verification of the dependencies between the indicators (accounted for in the research in accordance with the rules assumed in the model prepared) found that the perception of nutritional information quite strongly correlates with declared purchasing behaviour and the evaluation of the eating out establishment (Figure 1).

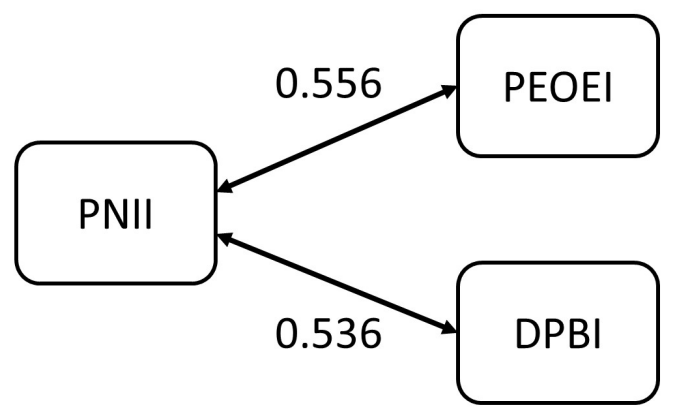

Figure 1 Dependencies between the perception of nutritional information (PNII) and declared purchasing behaviour (DPBI) and evaluation of eating out establishment (PEOEI).

\section{CONCLUSIONS}

The results of the research show that a high level of consumer acceptance of nutrition information, at eating out establishments, was found, even though it was poorly understood. The influence of perception of nutrition information on consumer opinion of eating out establishments and their purchasing decisions was also noted.

The results lead to the conclusion that providing nutritional information may be an activity, which increases the competitiveness of eating out establishments. It may also lead to more rational marketplace choices in terms of health. Moreover, when taking into consideration the growing popularity of eating out/away from the home, this may even have an impact upon social health.

\section{Acknowlegdgements}

This work was financial supported by the Faculty of Human Nutrition and Consumer Sciences, Warsaw University of Life Sciences (SGGW-WULS), Warsaw, Poland.

\section{Conflict of interest}

The authors declare no conflict of interest.

\section{REFERENCES}

1. AlexanderM., O'Gorman K., WoodK.: Nutritional labelling in restaurants. International Journal of Contemporary Hospitality Management, 2010; 22 (4): 572-579.
2. Auchincloss A.H., Mallya G., Leonberg B.L., Ricchezza A., Glanz K., Schwarz D.F.: Customer responses to mandatory menu labeling at full service chain restaurants. Am J Prev Med 2013a; 45 (6): 710-719.

3. Auchincloss A.H., Young C., Davis, A.L., Wasson S., Chilton M., Karamanian V.: Barriers and facilitators of consumer use of nutrition labels at sit-down restaurant chains. Public Health Nutr 2013b; 16 (12): 2138-2145.

4. Bes-Rastrollo M., Basterra-Gortari F.J., SánchezVillegas A., Mart A., Martínez J.A., Martínez-González M.A.: A prospective study of eating away-from-home meals and weight gain in a Mediterranean population: the SUN (Seguimiento Universidad de Navarra) cohort. Public Health Nutr 2010; 13 (9): 1356-1363.

5. Bollinger B., Leslie P., Sorensen A.: Calorie posting in chain restaurants. Am Econ J: Economic Policy 2011; 3 (1): 91-128.

6. Burton S., Creyer E.H., Kees J., Huggins K.: Attacking the obesity epidemic: the potential health benefits of providing nutritional information in restaurants. Am J Publ Health 2006: 96 (9): 1669-1675.

7. Carvalho D.R., Rodrigues Silva M.A.: Eating-out and experiential consumption: a typology of experience providers. Brit Food J 2014; 116 (1): 91-103.

8. Cowburn G., Stockley L.: Consumer understanding and use of nutrition labeling: a systematic revie. Public Health Nutr 2005; 8(1): 21-28.

9. Din N., Zahari M.S.M., Shariff S.M.: Customer Perception on Nutritional Information in Restaurant Menu. Procedia Soc Behav Sci 2010; 42: 413 - 421.

10. Drichoutis A.C., Lazaridis P., Nayga R.M. Jr: Consumers' use of nutritional labels: A review of research studies and issues. J Acad Mark Sci 2006; 10(9): 1-22.

11. Dumanovsky T., Huang C.Y., Bassett M.T.,Silver, L.D.: Consumer awareness of fast-food calorie information in New York City after implementation of a menu labeling regulation. Am J Publ Health 2010; 100(12): 2520-2525.

12. Elbel B., Kersh R., Brescoll V.L., Dixon L.B.: Calorie labeling and food choices: a first look at the effects on low-income people in New York City. Health Aff (Millwood) 2009; 28: 1110-1121.

13. Feunekes G.I., Gortemaker I.A., Willems A.A., Lion R., van den Kommer M.: Front-of-pack nutrition labelling: testing effectiveness of different nutrition labelling formats front-of-pack in four European countries. Appetite 2008; 50(1): 57-70.

14. Harnack L.: Availability of nutritional information on menus at major chain table-service restaurants. J Am Diet Assoc 2006; 106(7): 1012-1015

15. Harnack L.J., French S.A.: Effect of point-of-purchase calorie labeling on restaurant and cafeteria food choices: a review of the literature. Int $\mathrm{J}$ Behav Nutr Phys Act 2008; $5: 51$.

16. Hobin E., Lebenbaum M., Rosella L., Hammond $D$. : Availability, location, and format of nutritional information in fast-food chain restaurants in Ontario, Canada. Can J Diet Pract Res 2015; 76(1): 44-48. 
17. Hwang J., Lorenzen C.L.: Effective nutrition labeling of restaurant menu and pricing of healthy menu. Journal of Foodservice 2008; 19(5): 270-276.

18. Jarosz A., Kozłowska-Wojciechowska M., UramowskaŻyto B.: Oczekiwania konsumentów wobec informacji żywieniowej umieszczanej na opakowaniach produktów spożywczych [Expectations concerning nutrition information on the food products packaging]. Rocz Panstw Zakl Hig 2003; 54(2): 231-239

19. Josiam B., Foster C.: Nutritional information on restaurant menus: Who cares and why restauranteurs should bother. Int J Cont Hosp Man 2009; 21(7): 876 -891 .

20. Kant A., Graubard B.: Eating out in America, 19872000: trends and nutritional correlates. Am J Prev Med 2004; 38(2): 243-249.

21. Kearney J.M., Hulshof K.F.A.M., Gibney M.J.: Eating patterns - temporal distribution, converging and diverging foods, meals eaten inside and outside of the home - implications for developing FBDG. Public Health Nutr 2001; 4(2): 693-698.

22. Kowalczuk I., Czarniecka-Skubina E.: Eating out in Poland. History, Status, Perspectives and Trends. Scientific Journal. Service Management 2015; 16: 75 83.

23. Krukowski R., Harvey-Berino J., Kolodinsky J. Narsana R.T., Desisto T.P.: Consumers may not use or understand calorie labelling in restaurants. J Am Diet Assoc 2006; 106(6): 917-920.

24. Lachat C., Roberfroid D., Huybregts L., Van Camp $J$., Kolsteren P.: Incorporating the catering sector in nutrition policies of WHO European Region: is there a good recipe? Public Health Nutr 2009; 12(3): 316324.

25. Mayfield K.: Nutrition labeling for restaurant menu item: College students' preferences for nutritional information and its influence on purchase intention. Iowa State University, 2011, http://lib.dr.iastate.edu/cgi/ viewcontent.cgi? article $=3106 \&$ context $=$ etd. (accessed 20 August 2017).

26. McLean-Meyinsse P.E.: An analysis of nutritional label use in the Southern United States. J Food Distr Res 2001; 32(1): 110-114.

27. Mills J.E., Thomas L.: Assessing customer expectations of information provided on restaurant menus: a confirmatory factor analysis approach. J Hosp Tour Res 2008; 32(1): 62-88.

28. Ozimek I., Tomaszewska M.: Znaczenie wybranych źródeł informacji o produktach żywnościowych dla konsumentów. Handel Wewnętrzny 2011; 331(2): 4856 (in Polish; English abstract).

29. Pulos E., Leng K.: Evaluation of a voluntary menu labeling program in full-service restaurants. Am J Publ
Health 2010; 100(6): 1035-1039.

30. Radwan H., , Faroukh M. E., Obaid R. S.: Menu labeling implementation in dine-in restaurants: the Public's knowledge, attitude and practices. Arch of Public Health 2017, 75, 8.

31. Satia J.A., Galanko J.A., Neuhouser M.L.: Food nutrition label use is associated with demographic, behavioral and psychosocial factors and dietary intake among African Americans In North Carolina. J Am Diet Assoc 2005; 105(3): 392-402.

32. Swartz J.J., Braxto D., Viera A.J.: Calorie menu labeling on quick-service restaurant menus: an updated systematic review of the literature. Int $\mathrm{J}$ Behav Nutr Phys 2011; 8(1): 135.

33. Temple J.L., Johnson K., Recupero K., Suders H.: Nutrition labels decrease energy intake In adults consuming lunch in the laboratory. J Am Diet Assoc 2010; 110(7): 1094-1097.

34. Thomas L., Mills J. E.: Consumer Knowledge and Expectations of Restaurant. Journal of Foodservice 2006; 17(1): 6-22.

35. Vandevijvere S., Lachat C., Kolsteren P., Van Oyen H.: Eating out of home in Belgium: current situation and policy implications. Brit J Nutr 2009; 102(6): 921-928.

36. VanEpps E. M., Roberto C. A., Park S., Economos C. D., Bleich S.N.: Restaurant Menu Labeling Policy: Review of Evidence and Controversies. Curr Obes Rep. 2016, 5(1): 72-80.

37. Vyth E.L., Steenhuis I.H.M., Roodenburg A.J.C., Brug J., Seidell, J.C.Front-of-pack nutrition label stimulates healthier product development: a quantitative analysis. Int J Behav Nutr Phys Act 2010; 5: 65.

38. Warde A., Cheng S.L., Olsen W., Southerton D.: Changes in the practice of eating: a comparative analysis of timeuse. Acta Sociol 2007; 50(4), 363-385.

39. Waterlander W.E., Zenk S.N.: Food labelling, food retail availability and food pricing - moving from research to action? Public Health Nutr 2015; 18(1): 2-7.

40. Wootan M., Osborn M.: Availability of nutritional information from chain restaurants in the United States Am J Prev Med 2006; 30(3): 266-268.

41. Wu H.W., Sturm R.: What's on the menu? A review of the energy and nutritional content of US chain restaurant menus. Public Health Nutr 2013; 16(1): 87-96.

42. Yoon H. J., George T.: Nutritional information disclosure on the menu: focusing on the roles of menu context, nutritional knowledge and motivation. International Journal of Contemporary Hospitality Management 2012; 31(4): 1187-1194.

43. Zgliczyński W.: Obesity and overweight in Poland. 2017, https:/www.ceeol.com/search/article-detail?id=545693 (accessed 20 August 2017).

Received: 23.07.2018

Accepted: 08.02.2019 